\title{
King Solomon's Ambiguous Wife in the Queste del Saint Graal
}

\author{
Anastasija Ropa \\ Department of Management and Communication Science, \\ Latvian Academy of Sport Education
}

\begin{abstract}
Solomon's wife is one of the most ambiguous female characters introduced in the anonymous French Queste del Saint Graal, an early-thirteenth-century Arthurian romance. She appears in an account that relates the prehistory of the Ship of Solomon and that is embedded in the Grail quest narrative. Subsequent versions of the narrative, such as Thomas Malory's "Tale of the Sankgreal," transform her into an "evil," sinful wife. This paper explores the representation of Solomon's wife in two late medieval illuminated manuscripts of the LancelotGraal cycle.
\end{abstract}

Keywords: Queste del Saint Graal; gender studies; Arthurian women; the Grail quest; illuminated manuscripts; King Solomon. 


\title{
King Solomon's Ambiguous Wife in the Queste del Saint Graal
}

\author{
Anastasija Ropa \\ Department of Management and Communication Science, \\ Latvian Academy of Sport Education, Latvia
}

\section{Introduction. Duality of Solomon's Wife in the Queste del Saint Graal}

Solomon's wife is among the most ambiguous women characters in the anonymous French Queste del Saint Graal, an Arthurian romance written in the early thirteenth century; she appears in a "story within the story" that relates the prehistory of the Ship of Solomon. By hearing this story, the questers receive the final proof of Galahad's election. The story also highlights the role that Solomon's wife plays in building and furnishing the ship. Many previous syudies of the Queste categorizes the women characters of the romance into saints and demons. However, Solomon's wife, a woman who severely vexes her husband and whose intelligence baffles even the wise Solomon, falls in between the saintdemon binary. This uncertainty proved problematic for the Queste medieval audience, as attested by the fact that she becomes an unambiguously bad, evil wife in two subsequent texts retelling the same episode, the Estoire del Saint Graal and Thomas Malory's "Tale of the Sankgreal" (part of the Morte Darthur). These texts, however, are not the only sources that make an ambivalent presentation of women associated with King Solomon, who, after all, is depicted with women in illuminated Bibles and other devotional texts. Thus, in drawing Solomon's wife, the Queste and the Estoire illuminators could have relied on a range of visual sources beyond the text itself, and it is likely that these images would have influenced their portrayal of Solomon's wife in the manuscripts. The present paper explores the representation of 
Solomon's wife in two late medieval illuminated manuscripts of the Lancelot-Graal cycle: Paris, Bibliothéque nationale de France (BnF), fonds français (f. fr.) 749, folio (fol.) 52v (Estoire) and BnF, f. fr. 112 (3), fol. 169r (Queste).

In this essay, I first outline the basic plot of the Ship of Solomon episode and give a brief overview of the manuscript tradition and different versions of the episode. Next, I discuss in more detail the differences between the Queste, the Estoire and the Morte versions and the significance of these variations for the discourses on gender, family and marital affection within the context in which the respective manuscripts were circulated, reproduced and consumed. Subsequently, I provide a comparative examination of the iconography of King Solomon with various female figures, many of them symbolic, namely, the Queen of Sheba, Sapientia (Wisdom), Vanity and Justice. I contend that the duality of women represented with Solomon is replicated by the ambiguous nature of Solomon's wife in the Queste and her visual representation in BnF, f. fr. 112 (3). I analyze the image of Solomon's wife within the illuminative cycles of the Queste manuscripts in order to argue that Solomon's ambiguous wife exhibits certain similarities to Eve the mother of sin on the one hand and to Sir Perceval's sister on the other hand.

\section{King Solomon's Ship Episode in Different Versions of the Grail Quest}

The Queste del Saint Graail is part of the Lancelot-Graal cycle, which consists of L'Estoire del Saint Graal, L'Estoire de Merlin, Lancelot, La Queste del Saint Graal, and La Mort le roi Artu. The cycle is preserved in its entirety in nine manuscripts, ${ }^{1}$ as compared to the total of approximately 200 copies of parts of the cycle ${ }^{2}$ and fifty-six manuscripts presenting the complete Queste or its fragments.3 The romances of the cycle have

\footnotetext{
${ }^{1}$ Miranda Griffin, The Object and the Cause in the Vulgate Cycle (London: Legenda, 2005), $2-3$.

2 Alison Stones, "Seeing the Grail, Prolegomena to a Study of Grail Imagery in Arthurian Manuscripts," in The Grail: A Casebook, ed. Dhira Mahoney (London: Garland Publishing, 2000), 301-66 (302).

3 Fanni Bogdanow, "Little Known Codex, Bancroft ms. 73, and its Place in the Manuscript Tradition of the Vulgate Queste del Saint Graal," Arthuriana 6:1 (1996): 1-21 (2).
} 
different authors, all of them unknown, and were composed in the first half of the thirteenth century. The Queste was popular from the early thirteenth century, when it was written, to the sixteenth century, as confirmed by the number of surviving manuscripts produced across Europe, not only in France and England, but also, for instance, in Flanders and Italy. From the late fifteenth century onwards, the Queste appeared in printed editions. ${ }^{4}$ The Queste is also the source of Malory's "Tale of the Sankgreal," a choice which is remarkable in itself, because Malory had access to other versions of the Grail quest, both English and French, apart from the one presented in the Queste: John Hardyng's Chronicle, the French prose Tristan and, possibly, Perlesvaus. 5 These versions are less intensely religious than the Queste, so Malory's decision to follow the Queste text closely is noteworthy. For the other books of the Morte, Malory often combines several sources, but, in the "Sankgreal," Malory uses the Queste text as his only source, though his omissions and subtle alterations can result in changing the meaning of the original. ${ }^{6}$

${ }^{4}$ The first printed editions of the Queste produced by Antoine Vérard date from 1488 (see C. E. Pickford, "Antoine Vérard: Éditeur du Lancelot et du Tristan," in Mélanges de langue et littérature françaises du Moyen Age et de la Renaissance offerts à Charles Foulon (Rennes: Institut de français, Université de Haute-Bretagne, 1980), vol. 1, 280-84). On Vérard's editions of Arthurian romances, see Mary Winn, "Vérard's Editions of Tristan," Arthuriana 19:1 (2009): 47-73.

${ }^{5}$ On the French and English sources that were possibly available to Malory, see P. J. C. Field, "Malory and the Grail," in The Grail, the Quest and the World of Arthur, ed. Norris Lacy (Cambridge: D. S. Brewer, 2008), 141-55. See also Terence McCarthy, "Malory and His Sources," in A Companion to Malory, ed. Elizabeth Archibald and A. S. G. Edwards (Cambridge: D. S. Brewer, 1996), 75-95. On Malory's use of Hardyng's Chronicle, see Ralph Norris, Malory's Library: The Sources of the Morte Darthur (Cambridge: D. S. Brewer, 2008), 15-18.

${ }^{6}$ The studies of Malory's treatment of the Queste have a long history, beginning from Vinaver's edition of the Morte; the development of these studies is described by Roberta Davidson, "The 'Freynshe booke' and the English Translator: Malory's Originality Revisited," Translation and Literature 17:2 (2008): 133-49 (dealing with Malory's claimed sources for the entire Morte). A detailed, if somewhat dated, study of Malory's changes to the Queste is S. N. Ihle, Malory's Grail Quest: Invention and Adaptation in Medieval Prose Romance (London: University of Wisconsin Press, 1983). See also Dhira Mahoney, "The Truest and Holiest Tale: Malory's Transformation of La Queste del Saint Graal," in Studies in Malory, ed. James Spisak (Kalamazoo: Medieval Institute Publications, 1985), 109-28, P. E. Tucker, "The Place of the Quest of the Holy Grail in the Morte Darthur," MLR 48 (1953): 391-97, Charles Moorman, "Malory's Treatment of the Sankgreal," PMLA 71 (1956): 496-509, Moorman, “The Tale of the Sankgreall': Human Frailty," in Malory's 
In both the Queste del Saint Graal and Thomas Malory's "Tale of the Sankreal," the Ship of Solomon episode represents a "story within a story," which the elect knights Sir Galahad, Sir Perceval and Sir Bors either read (Queste) or hear ("Sankgreal") on board the ship constructed on the bidding of King Solomon's wife. The story confirms Galahad's descent in direct line from King Solomon himself and the knight's right to the Holy Grail as his heirloom. In the Queste and the "Sankgreal," the story is preceded by the apocryphal narrative of the Fall and the planting of the Tree of Life, the wood of which is used to construct some of the furniture on the ship. The episode, thus, takes the audience into the realm of Biblical history and apocrypha, underscoring the sinfulness of women prior to the Virgin Mary.

In the episode, King Solomon appears as a man disturbed by the practical wisdom and intelligence of his unnamed wife. He prays to God, and a celestial voice promises him consolation: an heir, a powerful and virginal knight (Sir Galahad), would come of his line. Then Solomon becomes concerned about communicating to the future heir that he, Solomon, knew of the knight's coming all along. Solomon's wife suggests building a marvellous ship, which will hold precious heirlooms destined to the elect knight: the heirlooms are a bed, three coloured spindles carved from the Tree of Life, Solomon's sword and a purse containing a writ with the above narrative the historic events. Solomon's wife oversees the construction of the bed, and Solomon refurbishes the sword of David, for which his wife provides ignoble hangings of hemp. A noble virgin (Perceval's sister) is to replace these poor hangings by the fitting ones, made of her own golden tresses.

The basic events of the episode are the same in the Queste, the Estoire and the "Sankgreal": only their interpretation and the assessment of Solomon's wife are different. In the Queste, Solomon's wife is a complex, ambiguous character, at once shrewd and loving, concerned to help her husband and to retain her sovereignty. Indeed, as I contend further in the paper, Sovereignty, one of the female figures associated

Originality: A Critical Study of Le Morte Darthur, ed. R. M. Lumiansky (Baltimore: Johns Hopkins Press, 1964), 184-204, Jill Mann, "Malory and the Grail Legend," in A Companion to Malory, ed. Archibald and Edwards, 203-20, and Joerg Fichte's essay 6 in From Camelot to Obamalot: Essays on Medieval and Modern Arthurian Literature (Trier: Wissenschftlicher, 2010). 
with Solomon in high and late medieval iconography, can, in certain respects, be compared to Solomon's wife in the Queste. Meanwhile, in the Estoire, the author manifests clear hostility to "weak" and "sinful" women, recasting Solomon's wife as a cowardly, selfish courtesan, who seeks dominion over Solomon because she is afraid the king might do something against her. Malory, in turn, describes Solomon's consort as an "evyll wyff": in the English text, she comes across as an irrational, whimsical and tyrannical woman, who is both ignorant and ambitious.

\section{Perspectives on Gender, Family and Dynasty in Solomon's Ship Episode}

The Old Testament includes several texts ascribed to King Solomon, such as the Parables, the Ecclesiastes, and the Song of Songs. In fact, the Queste author quotes a well-known passage from the Ecclesiastes at the beginning of the episode: "I have found one man among a thousand, but I have not found a woman among all" (Ecclesiastes, 7:28). In the romance, however, the Queste author mistakenly refers the reader to the Parables, suggesting that, albeit general knowledge about Solomon's writings was common, the Queste author was not worried about precise attribution of the words: "il dis ten son liure que on apiele parabole. 'J'ai auiroune le monde, et alei parmi en tel maniere comme sense morteus port encherkier. Ne onques en chele circuite ne poi trouuer vne boine feme" "[He states in his book, called the Parables. 'I have circled the globe and searched it as thoroughly as any man can, but in all my wandering I have not found one good woman.'] ${ }^{7}$ All of Solomon's texts were hugely popular among medieval audiences, as were the accounts of Solomon's wisdom and justice; these virtues, exhibited by Solomon, are often illustrated on miniatures at the beginning of the Ecclesiastes, where the qualities are portrayed as women.

In the Queste, the story of Solomon and his wife is placed so as to recall a transition between the fall, presented in the section about Adam and Eve, and redemption, which is to come as the result of Galahad's achieving the Grail. The account about Solomon and his wife also

\footnotetext{
${ }^{7}$ La Queste del Saint Graal, Roman du XIII siècle, ed. Albert Pauphilet, 3 ${ }^{\text {rd }}$ edn. (Paris: Champion, 1923), 222, The Quest for the Holy Grail, trans. Jane Burns, The Old French Arthurian Vulgate and Post-Vulgate in Translation (Cambridge: D. S. Brewer, 2010), 136.
} 
marks a transition between biblical history (the story of Adam and Eve), and the fictional history of the Grail told in the Queste. Albert Pauphilet identifies the source of the story of Adam and Eve as a variation of the apocryphal Vita Adae et Evae. ${ }^{8}$ However, according to Emmanuèle Baumgartner, the Queste author altered the focus of the legend so as to replace Solomon's Temple, built around the Tree of Life, by the ship of Solomon. ${ }^{9}$ Baumgartner maintains that the ship symbolizes both the Church and the concept of transition between stages of initiation, the latter being highlighted through the presence of a bed. ${ }^{10}$ The account of Solomon's ship's construction immediately precedes the decisive proof of Galahad's messianic role, and this proof is Galahad's ability to join the pieces of David's sword, left for him on the ship. Moreover, the consecutive narratives about, first, Adam and Eve and, next, Solomon and his wife, bridge the Old Testament of the Grail history and the New Testament of Galahad's arrival. ${ }^{11}$ Frederick Locke contends that "the Eve la pecheresse episode and the building of the ship of Solomon are necessary to the progressive unfolding of the book, and indeed lead to the central action of the Queste, the uncovering of the mysteries on board that strange vessel." 12 Although the account of Solomon and his wife does not advance the narrative action, it becomes essential for the correct interpretation of events, and the

\footnotetext{
${ }^{8}$ See Albert Pauphilet, Études sur La Queste del Saint Graal' attribué à Gautier Map (Paris: Champion, 1921), 146-51, for a discussion of this apocryphal legend and its adaptation in the Queste. Vita Adae et Evae, which sometimes appears as the Penitence of Adam or as an introduction to the Golden Legend, was a popular medieval apocryphal legend. The evolution of the Adam and Eve legend in medieval Europe is described by Brian Murdoch, The Apocryphal Adam and Eve in Medieval Europe: Vernacular Translations and Adaptations of Vita Adae et Evae (Oxford: Oxford University Press: 2009).

${ }^{9}$ Emmanuèle Baumgartner, L'Arbre et le Pain, Essai sur la Queste del Saint Graal (Paris: S.E.D.E.S., 1981), 136. Baumgartner notes that the vessel usually described as "Solomon's ship" is in fact Solomon's wife's ship. For ease of reference, the term "Solomon's ship" is used throughout the article.

10 Baumgartner, L'Arbre, 136-37.

11 Pauline Matarasso argues the usefulness of seeing the Queste in terms of the Old and New Testament, because "if the Queste is seen as the New Testament fulfilling the Old Testament typified in the Josephus sections it gains immensely in literary unity" (Pauline Matarasso, The Redemption of Chivalry: A Study of the Queste del Saint Graal (Genève: Droz, 1979), 242). The Estoire, which was written after the Queste, functions as the Old Testament to the New Testament Queste account of redemption.

${ }^{12}$ Frederick Locke, The Quest for the Holy Grail: A Literary Study of a Thirteenth-Century French Romance (Stanford: Stanford University Press, 1960), 35.
} 
Queste author describes the relations between Solomon and his wife in detail. In turn, the episode is much shorter in the "Sankgreal," where Malory's omissions sometimes obscure the relation between the events and the characters' motivations: for instance, it is not clear in the "Sankgreal" why Solomon's wife comes up with the idea of building a ship. In his narrative, Malory makes no attempt at explaining the complexity of Solomon's relationship with his wife or at rationalizing Solomon's need to communicate knowledge about their lineage to his remote heir, Galahad. It seems that Malory relies on his audience sharing his opinion on family and genealogy, in this case, how a wife should behave and why a noble person must strive to leave a memento to his descendants, as well as on the fact that his audience might know the story already. Moreover, if Malory's readers are not familiar with the story of Solomon as embedded in the Grail narrative, they must have seen Solomon represented with female figures in visual sources, including the portrayal of Solomon with vices and virtues portrayed as women in illuminated Bibles.

In the Queste and the "Sankgreal" (as well as, to an extent, in the Estoire), the issues of family, history and genealogy are prominent throughout the ship of Solomon episode. However, the emotional dimension of Solomon's family life is represented differently in these three texts, with only the Queste author mentioning that Solomon's wife loved her husband. Unlike the Queste author, the Estoire author does not mention the love of Solomon's wife for her husband. Instead, the Estoire author emphasizes, with certain disapproval, Solomon's indulgence with his wife and criticizes the woman's deceptiveness. In both narratives, Solomon's wife enjoys certain authority, even though the authors may be apprehensive or disparaging about female capacity to govern. At least two illuminators to the Queste and the Estoire stressed the authority of Solomon's wife by placing her next to David's sword (BnF, f. fr. 112 (3), fol. 169r for the Queste and BnF, f. fr. 749, fol. 52v for the Estoire). Analogous symbolism is in place in the miniatures where Solomon himself receives a sword from an allegorical female figure, Justice, in BnF, f. fr. 164, fol. 219r.

The Estoire author deplores Solomon's infatuation, inspired by the woman's physical beauty, which leads the king to sin and dishonour. ${ }^{13}$

${ }^{13}$ For instance, the Estoire author comments: "par biauté de feme fu il si sorpris et deceüz qu'il en fist tant de choses contre Deu que a honte li pot l'en atorner" (L'Estoire 
In the place where the Queste author states that Solomon's wife loved him well, the Estoire author alters the entire motivation behind the woman's desire to know the cause of Solomon's concern: "Longuement penssa Salemons a ceste chose, et tant que la feme qe il amoit s'aperçut bien que il estoit chaoiz en tel pensé dont il ne pooit son cuer oster; si en fu trop a malese, car ele ot maintenant peor qe il n'eüst pensé a li malfaire." [Solomon thought for a long time about this, so much that his wife noticed that he was thinking about something he could not get out of his mind. She was very troubled, for she feared right away that he wanted to hurt her. $]^{14}$ In this sentence, the Estoire author brings out a contrast between Solomon's love and his wife's fear.

In the Queste and the Estoire, Solomon's wife waits for a convenient moment to ask her husband what grieves him, approaching him one evening when he appears to be more cheerful than usual. ${ }^{15}$ However, the Queste and, especially, the Estoire authors appear to be suspicious about her motivation: the Estoire author states that the woman feared lest Solomon might do something against her. The preceding narrative would remind the audiences that mankind had been condemned through a woman's (Eve's) sin and the redemption was mediated through an exceptional, virginal wife, Mary. According to Georges Duby, the twelfth-century clerical discourse described marriage as an unequal relationship in which affectio [affection] and dilectio [pleasure]

del Saint Graal, ed. Jean-Paul Ponceau (Paris: Champion, 1997), ii, 281) [he was so overcome and deceived by a woman's beauty that he did many things against God, which could lead him to shame] (translation mine).

${ }^{14}$ L'Estoire, ii, 283, The History of the Holy Grail, trans. Carol Chase (Cambridge: D. S. Brewer, 2010), 153.

15 In the Queste, the conversation takes place in the evening: "Si ne li volt pas tantost demander, ainz atendi tant qu'ele vit son point et qu'ele vit un soir qu'il estoit liez et joianz et qu'il estoit bien de lui" (Queste, 221) [She did not want to ask him immediately, but waited for the right occasion, until one evening she saw he was happy and joyful and in a good mood] (Quest for the Holy Grail, 136). In the Estoire, even greater intimacy between the spouses is hinted at: "Une nuit qu'il estoient ensemble avint qu'il fu un pou plus haitiez et plus envoisiez que il ne selt"' (Estoire, ii, 283) [One night when they were together, it happened that he was slightly more spirited and well-disposed than usual] (translation mine). In the "Sankgreal," the circumstances of the conversation are not specified, but Malory notes that "she wayted hir tyme" (Thomas Malory, The Works of Sir Thomas Malory, ed. Eugene Vinaver, $3^{\text {rd }}$ rev. edn. P. J. C. Field (Oxford: Clarendon, 1990), vol. 2, 992). 
was expected on the husband's part, while the wife was supposed to demonstrate respect. ${ }^{16}$ The Estoire and the Queste were written in the first half of the thirteenth century, when the attitudes described by Duby were probably giving ground to a somewhat more egalitarian relationship. Thus, the Estoire author may be looking back to the model of hierarchical marriage, while the Queste author appears to support the ideal of mutual love expressed by clerical authors in the thirteenth century and later.

Solomon's wife might be expected to take an active role in resolving the problem that concerns Solomon, because spouses would naturally collaborate on furthering the family honour and on transmitting genealogical information to posterity. Although Solomon can be reasonably sure about the immediate future of his lineage, the building of the ship is necessitated by the distance between him and the perfect knight who is to be the last of his blood. In the Estoire, Solomon is determined to make his descendant aware that Solomon has known of the knight's coming long before his birth. The Estoire author explains Solomon's desire by the fact that Solomon himself would not be able to see the knight:

Ie ne le verrai pas, car trop a lonc terme de cestui tens jusq'a celui de lors. Certes, se je en nule maniere li pooie faire savoir coment, si grant tens devant sa naissance, ai seüe novels de sa venue, je li feïsse savoir, mais je ne voi mie coment ce puisse ester, car jusq'a celui terme a dou mile anz ou plus.

I won't see Him, for it is too far away in time from now until then. Certainly if there were some way to tell him how I knew the truth about Him long before His birth, I would do so. But I don't see how, for the time is two thousand years and more away. ${ }^{17}$

The emphasis is on visual perception; Solomon is denied the joy granted to the reader of the illuminated copies of the Lancelot-Graal cycle, that of seeing the perfect knight. In the Queste, the same idea is expressed less emotionally, and the visual dimension is missing: "Si

\footnotetext{
16 See Georges Duby, Love and Marriage in the Middle Ages, trans. Jane Dunnett (Chicago: University of Chicago Press, 1988), 24-25.

${ }^{17}$ Estoire, 283, History of the Holy Grail, 153.
} 
pensa coment il poïst fere savoir a celui home derreain de son lignage que Salemons, qui si lonc tens avoit devant lui esté, seust la verité de sa venue" [he thought about how he might communicate to the last man in his line that he, Solomon, who had lived so long before him, had known that he was coming]. ${ }^{18}$ The Queste Solomon is primarily concerned with the transmission of family history, rather than entertaining the desire to see his famous heir. In the "Sankgreal," the problem of transmitting knowledge about one's descent is not mentioned. Instead, Solomon is concerned with the identity of his heir: "ever he mervayled and studyed who that sholde be, and what hys name myght be." 19 In fact, Solomon's ship is an analogue of visual genealogies constructed by Malory's contemporaries, the fifteenthcentury English gentry. The ship's grandeur and its marvels are a means of attracting attention, as much as the gentry memorial brasses were. The difference between Solomon's ship and visual genealogies is that the symbolism of Solomon's ship is directed towards a particular onlooker, who is Solomon's heir, unlike the gentry memorials in churches, which invited the attention of all parishioners. It is, perhaps, not coincidental that the only miniature showing Solomon and his wife in the Queste is part of a cycle that also depicts Adam and Eve, constituting another visual genealogy in a fifteenth-century manuscript of French provenance (Bibliothetque national de France, f. fr. 112 (3)).

In addition to the visual genealogy of the ship itself, there is a written genealogy contained on board: while the ship, the bed with its furnishings and David's sword are visual reminders of the grandeur of Solomon's lineage, the letter found on the bed provides information about Galahad's forebears up to King Solomon. In the Queste, the "contes" tells the audience about the ship-building while the companions are gazing at the bed with the three coloured spindles, ostensibly lest anyone should have doubts that the spindles "estoient naturieux colors sanz peinture, car eles n'i avoient esté mises par home mortel ne par fame" [were natural, not artificial; they had not been painted by human hand, either male or female]. ${ }^{20}$ Malory's translation is factual, obscuring the marvellous nature of the spindles: "Of these

\footnotetext{
18 Queste, 221, Quest for the Holy Grail, 136.

19 Thomas Malory, The Works of Sir Thomas Malory, ed. Eugene Vinaver, 3 $3^{\text {rd }}$ rev. edn. P. J. C. Field, vol. 2. Oxford: Clarendon, 1990, 992.

${ }^{20}$ Queste, 210, Quest for the Holy Grail, 130.
} 
three colowres were thes spyndyls, and of naturall coloure within, and withoute ony payntynge." 21 The Queste author claims he wants to suppress disbelief on the part of his audience, which makes him proceed to explanation without delay:

Et por ce que maintes genz le porroient oïr qui a mençonge le tendroient, se len ne lor faisoit entendent coment ce poroit avenir, si s'en destorne un poi li contes de sa droite voie et de sa matiere por deviser la maniere des trois fuissiax qui des trois colors estoient.

[since many listeners might find this tale hard to believe if they were not told just how this could have happened, the story here veers away from its straight path and its rightful subject to describe the three colored spindles.] ${ }^{22}$

The companions learn the same story from the letter they find in a purse: "Lors commence Perceval a lire ce qui ert ou brief, et tant qu'il lor devise la maniere des fuissiax et de la nef einsi come li contes l'a devisee" [Perceval began to read the letter, which described the nature of the ship and its spindles, just as the story has narrated]. ${ }^{23}$ The period in which the audience would have read or listened to the lengthy account is constructed as equivalent to the time the companions spend transfixed in front of the bed. The Queste author continues at exactly the same place where he had left the companions: "Or dit li contes que grant piece regarderent li troi compaignon le lit et les fuissiax, et tant qu'il conurent que li fuissel estoient de naturel color sanz peinture" [The story now says that the three companions stared at the bed for so long that they understood its spindles to be naturally colored rather than painted]. ${ }^{24}$ At this point, the emphasis is on the visual aspects of the scene, with the colours of the three spindles being stressed throughout the narrative. The coloured spindles are depicted in illuminations to the Queste: BnF, f. fr. 112 (3), fol. 169r shows Solomon and his wife, and on fol. 170r Bors and Galahad marvel at the spindles, as Perceval is reading the letter.

21 Malory, Morte, 990.

${ }^{22}$ Queste, 210, Quest for the Holy Grail, 130.

23 Queste, 226, Quest for the Holy Grail, 139.

24 Ibid. 
The Queste author describes the knights' reaction as wonder, and the long period they spend examining the spindles indicates the strength of their amazement: "si s'en merveillierent mout, car il ne sorent coment ce pooit avenir" [This amazed them, and they did not know how it was possible]. ${ }^{25}$ The word "merveille" [marvel] and its derivatives are prominent in the account of the ship construction. The word is used by Solomon, his wife and the narrator to describe the ship, David's sword, together with its handle and sheath, and the bed. The ship is "la plus merveilleuse nef qui onques fust veue" 26 [the most marvellous ship that was ever seen], the sword - "la plus trenchant et la plus merveilleuse qui onques fust bailliee de main de chevalier" 27 [the sharpest and most marvellous that was ever wielded by a knight], and the bed - "grant et merveilleux" 28 [huge and marvellous]. ${ }^{29}$ Solomon's evaluation of his wife's work indicates why these things are marvellous: "Tu as, fist il, merveilles fetes. Car se tuit cil monde estoient ci, si ne savroient il deviser la senefiance de ceste nef se Nostre Sires ne lor enseignoit, ne tu meesmes, qui l'as fete, ne ses que ele senefie" [You have accomplished something wondrous. If all the world were here, they would not know how to interpret the meaning of this ship unless Our Lord instructed them; even you who had it built don't know what it means]. ${ }^{30}$ For Solomon, the ultimate source of wonder is the incomprehensibility of the ship's significance rather than physical characteristics of the objects on it. Nancy Regalado comments that, in the episode, "the insufficiency of signs renders them unintelligible, not to their readers, but to their makers. [...] Full understanding of such special, prophetic signs calls for 'some other help' from the Lord:

25 Ibid.

${ }^{26}$ Queste, 222.

${ }_{27}$ Queste, 223.

28 Ibid.

29 Translations are my own; Burns uses other epithets ("finest," "most amazing" and "magnificent," respectively, Quest for the Holy Grail, 137) to translate the word "merveilleux" used by the French author. In her review of the translation, Radulescu comments on Burns's way of rendering the French "merveille," noting that "Burns uses "marvel" sparingly, and only where it suits the atmosphere best" (Raluca Radulescu, "Review of Burns, E. Jane. The Quest for the Holy Grail. The Old French Vulgate and PostVulogate in Translation," The Medieval Review (2011), http://hdl.handle.net/2022/13321 (accessed 2 December 2016)).

${ }^{30}$ Queste, 224-25, Quest for the Holy Grail, 138. 
interpretation requires revelation." 31 From Solomon's viewpoint, the ultimate source of wonder is the inevitable failure of interpretation by anyone, including his wife, except for the knight for whom the heirloom is destined.

Earlier in the episode, there are two points at which Solomon's wife teaches the king: she explains that contact between Solomon and his remote descendant Galahad can be established through a ship and that the best present to the knight would be David's sword. However, Solomon declares that neither his wife nor anyone in the world would be able to understand the symbolism of the ship. The spindles' colour and the ship's interpretation are manifestations of divine grace, inspiring wonder and, possibly, even religious adoration in the observers. The Queste author inserts lengthy stories about the Tree planted by Eve and about Solomon's ship between the moment when the knights find the bed and the moment they hear the stories. It seems that the ship must be marvellous to draw the attention of the onlooker and to make sure that the memory of Solomon's line does not disappear, just as the lavish illumination of certain Lancelot-Graal manuscripts contributed to their survival.

Although Solomon claims that his wife will be unable to interpret the ship's meaning, it seems that, like Solomon, his wife has been granted revelations of her own. Thus, the audience is not told how Solomon's wife knows about the coming of a maiden who will bring a suitable girdle for David's sword. In the Queste, Solomon's wife assures the king that they should not put a good girdle for the sword: "il n'afiert mie a nos que nos les i metons; ainz les i metra une pucele, mes je ne sai quant ce sera, ne a quele hore" [(i)t's not up to us to attach the proper belt to this sword. A virgin will do that, though I don't know when]. ${ }^{32}$ As a result, Regalado's suggestion that the "deficient understanding [of Solomon's wife] is represented by the hemp belt she attaches to the shining sword of David" requires qualification. ${ }^{33}$ In the Queste, both King Solomon and his wife are unable to provide suitable hangings for the sword, indicating their incomplete understanding of the ship's signification.

\footnotetext{
${ }^{31}$ Nancy Regalado, “The Medieval Construction of the Modern Reader: Solomon's Ship and the Birth of Jean de Meun," Yale French Studies 95 (1999): 81-10 (89).

${ }^{32}$ Queste, 223, Quest for the Holy Grail, 138.

33 Regalado, "Medieval Construction," 89.
} 
On the other hand, Regalado's comment is appropriate for the explanation in the "Sankgreal." There, Solomon's wife prophesies the coming of Perceval's sister and the questing knights, but does not say what will happen to the girdle: "Sir, wyte you welle that I have none so hyghe a thynge whych were worthy to susteyne soo hyghe a swerde. And a mayde shall brynge other knyghtes thereto, but I wote not whan hit shall be ne what tyme." ${ }^{34}$ Remarkably, Malory translates precisely the end of the woman's utterance, where she confesses that there are limitations to her knowledge: "I wote not whan hit shall be ne what tyme" is a literal translation of "mes je ne sai quant ce sera, ne a quele hore." The importance of the sword and the girdles is further confirmed in visual sources. For the Queste, the sword is depicted in $\mathrm{BnF}$, f. fr. 112 (3) on fol. 169r, where it becomes the focus of Solomon's and his wife's attention, and on fol. 170r, where the sword is depicted in the foreground, even as the attention of the knights is divided between the spindles and the letter. For the Estoire, the sword is pictured between Solomon and his wife standing on the ship in $\mathrm{BnF}, \mathrm{f}$. fr. 749 , fol. $52 \mathrm{v}$. The sword of sovereignty is also a symbolic object that Justice hands to Solomon in a historiated Bible (BnF, f. fr. 164, fol. 219r).

Despite the claims at authority by Solomon's wife in the Grail texts and two illuminations, where she is associated with objects denoting power (sword) and lineage (spindles), and the depiction of Justice and Wisdom (BnF, f. fr. 160, fol. 255v) in historiated Bibles, the woman stills seems excluded from the male-centred genealogy of Galahad's ancestors. This is can be understood by reference to the historical context for the Queste, the Estoire and the "Sankgreal." Indeed, Duby and Denton maintain that, for the late twelfth-century French nobility and for the late fifteenth-century English gentry respectively, ensuring a family's future well-being and transmitting the lineage's past achievements through a written genealogy was an ostensibly male prerogative; according to Denton, "Family history was taught by fathers, ancestors, and 'old knights and esquires'." 35 Moreover, in the Queste and the Estoire, male characters appear to hold the monopoly on such knowledge, and Jennifer Looper argues that

\footnotetext{
34 Malory, Morte, 993.

${ }^{35}$ Denton, "Genealogy," 144-145.
} 
The genealogies in the Estoire and the Queste, designed to showcase the extraordinary nature of their final product, are [...] built on the marginalization of their female members by insisting on a "realistic" patrilineal family tree that pushes to an extreme the contemporary omission of women from prestigious genealogies. ${ }^{36}$

However, it is likely that, in practice, the female and male family members worked together to ensure that the family's well-being and honour would be sustained through arranged marriages as well as production and education of heirs and that the illustrious past of their family would be remembered in written - and visual - genealogies. The attention Solomon's wife pays to preparing David's sword so that it would become a treasured and meaningful heirloom to Galahad, highlighted by her intent gazing at the sword in BnF, f. fr. 113(2), fol. $169 r$, confirms her genealogical concerns. Likewise, the engagement of Solomon's wife in preserving the lineage is depicted in the Estoire illumination that shows her leaning to the sword, her hands outstretched (BnF, f. fr. 749, fol. 52v). The role which Solomon's wife plays in designing the ship illustrates the co-operation of spouses in this area, and, in the Queste, the author indicates that Solomon trusts in his wife's resourcefulness. When she asks Solomon about the cause of his concern, Solomon realizes at once that she would be able to help him:

Quant Salemons oï ceste parole, si pensa bien que, se cuers mortiex pooit metre conseil en ceste chose, que ele l'i metroit, car il l'avoit trovee de si grant engin qu'il ne cuidast mie qu'il eust ame de si grant engin ou siecle qui le poïst penser.

[Solomon considered the offer, thinking that if any human mind could help him solve this matter, it would certainly be his wife. He had found her to be more shrewd than anyone he could think of. $]^{37}$

Although in the Queste Solomon praises his wife's cleverness, she is criticized by both the Queste author and Malory, probably because of her assertive behaviour. Thus, underlying the story of the ship building,

\footnotetext{
${ }^{36}$ Jennifer Looper, "Gender, Genealogy, and the 'Story of the Three Spindles' in the Queste del Saint Graal," Arthuriana 8:1 (1998): 49-66 (52).

${ }^{37}$ Queste, 222, Quest for the Holy Grail, 136-37.
} 
another discourse, on authority and gender roles in family, is manifest. It seems that the main difference between bad women, such as Eve and Solomon's wife, and good women, such as Mary and Perceval's sister, is their position in relation to men. Remarkably, when Solomon is depicted with women in another context, that of historiated Bibles, he is usually in the dominant position, as on the illumination with the Queen of Sheba (BnF, f. fr. 160, fol. 161v), unless the female figure represents a quality or concept.

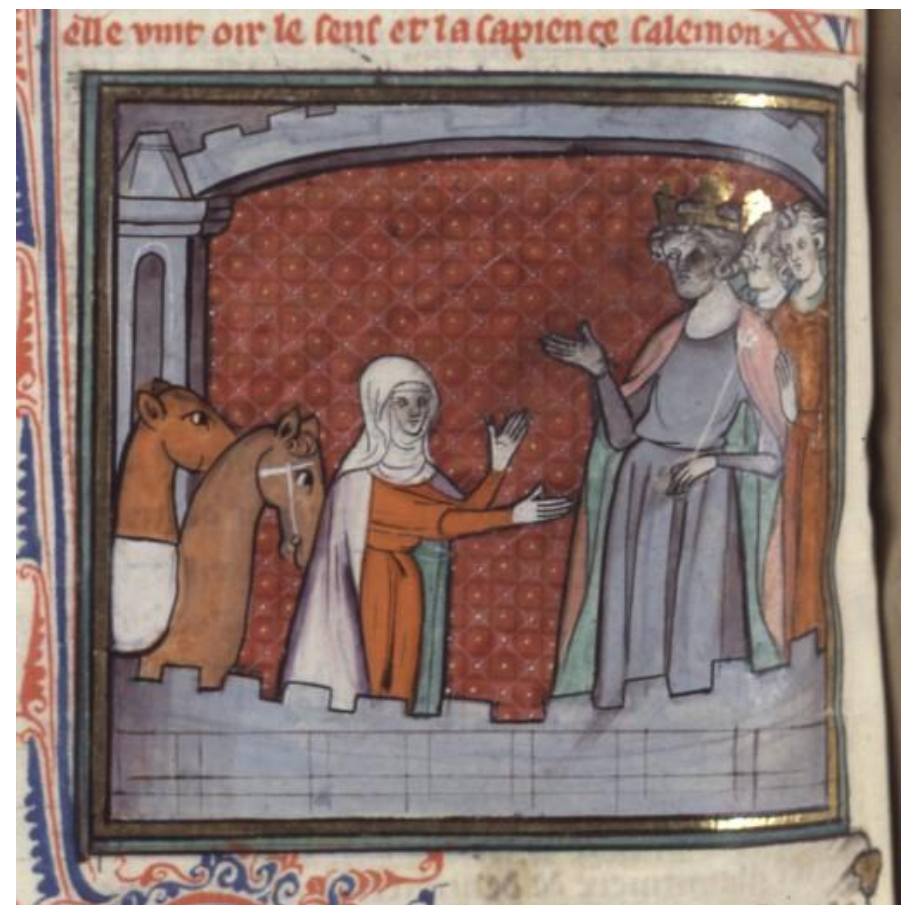

Fig. 1. Solomon and Wisdom, Guiard des Moulins, Bible Historiale. c. 1300-1325, Paris. Bibliothetque national de France, Ms. Fr. 160, fol. 161v.

Thus, a typical caption in a manuscript of the French historiated Bible, translated by Guiard de Moulins, reads: "de la royne sabba quant elle vint oir le sens et la sapience salemon. XXVI" [of the Queen of 
Sheba when she went to hear the sense and wisdom of Solomon]. ${ }^{38}$ In the illumination, the Queen is approaching Solomon from the left. She is placed lower than Solomon and is raising her hands to the king in a humble attitude. Her placement and posture indicate her subordinate position, while the king's authority is highlighted by his crown and his somewhat withdrawn posture. He has two courtiers behind him, while the Queen of Sheba is depicted with two camels, and her exotic beasts of burden provide a contrast to Solomon's human retinue. The Queen of Sheba is represented as symbolically inferior to Solomon, who stands for culture and learning. The woman seems to recognize her lower standing in respect to Solomon, providing a role model in her respect and deference to male wisdom. Solomon's wife in the Queste, the Estoire and the "Sankgreal" defies this model of humble deference by her authoritative actions, and this defiance is to an extent stressed in miniatures to the Queste and, especially, the Estoire, where her position is that of a consort and an equal.

Humility and its opposite, arrogance, displayed by women characters towards male ones are at the heart of the Ship of Solomon episode. ${ }^{39}$ Thus, an important virtue demonstrated by Perceval's sister in the Queste and the "Sankgreal," apart from her virginity, is her respect towards Galahad. ${ }^{40}$ Conversely, the principal "sin" of Solomon's wife is her claim to power, which she exercises not only over Solomon's subjects but also over him. Malory sometimes calls her "lady" and "madam" when addressed by the carpenter, ${ }^{41}$ but just as often she appears as "wyff." 42 The French author uses the word "dame" in the cases corresponding to Malory's "lady" and "madam," but he also uses the word "femme" ("wyff" in the "Sankgreal"). As in the "Sankgreal," the Queste wife is identified as "dame" when she orders the bed to be brought ${ }^{43}$ and when she commands carpenters to make the spindles. ${ }^{44}$

\footnotetext{
38 Translation mine.

39 On the somewhat marginal status of humility as a virtue in the Middle Ages, see Michel Zink, L'Humiliation, le Moyen Âge et nous (Paris: Albin Michel, 2017).

40 Symbolically, Perceval's sister expresses her respect towards Galahad when she offers him the girdles made of her hair.

41 Malory, Morte, 992, 993.

42 Four times within the episode, Malory, Morte, 991-94.

43 "Quant la nef fu fete et mise en mer, la dame i fist metre un lit grant et merveilleux" (Queste, 223) [Once the ship has been built and launched, Solomon's wife had a huge and magnificent bed put in it (Quest for the Holy Grail, 137)].
} 
She is described as Solomon's wife ("fame") when she explains that a peerless knight would enter the ship and that Solomon should prepare fitting arms for the knight. Remarkably, the word "lady" is used by the author for the first time when she is about to instruct Solomon what to do with King David's sword. ${ }^{45}$ It is also the only piece of advice that Solomon does not follow, possibly because, as a man, he is supposed to know better how to prepare his sword for it to become a suitable gift for his heir.

Meanwhile, in illuminated Bibles, where Solomon is often depicted with women at the beginning of the Ecclesiastes, the women do not always show the same deference as the Queen of Sheba. One notable instance of a female figure used as a negative example of how women ought to behave in relation to a wise man comes a historiated Bible (BNF, f. fr. 162, fol. 11r). The Ecclesiastes is announced with a red-ink caption "ci fenissent les paraboles salemon. ci commencent ecclesiastice" and a miniature showing Solomon and a female figure. The lady on this miniature is Vanity, standing in front of the king and boldly pointing with the index finger of her left hand. With her right hand, Vanity holds the folds of her blue surcoat. On her head, Vanity bears an ornate headdress, but no crown. Solomon, seated on an elevated pedestal with a rod, the sign of royal power, in his right hand, wears a crown. Solomon seems to be sustaining a discussion or argument with Vanity, answering her points with a gesture of his open left hand. The Vanity's gesture is assertive, even aggressive, her straightened hand and pointing finger invading Solomon's space. Solomon, on the other hand, seems reticent, swaying away from Vanity. Spatially, his seated figure occupies more space than that of Vanity: Solomon's foot, extended over the pedestal, takes over half of the framed miniature, and he is also placed higher than Vanity, due to the pedestal and the tall crown on his head.

There is some resemblance between the figures of Solomon and the symbolic woman in the Ecclesiastes (in the above case, Vanity) and Solomon and his wife in the Queste. The assertion of sovereignty and willful self-exhibition, demonstrated by the Vanity in the Ecclesiastes miniature, are exactly those traits of Solomon's wife in the Queste that

44 "la dame resgarda le lit et dist que encore il failloit il" (Queste, 224) [the woman felt that the bed lacked something (Quest for the Holy Grail, 138)].

45 Malory, Morte, 992. 
has earned her the opprobrium of the later authors of the Estoire and the "Sankgreal." Thus, after the ship is constructed, Solomon's wife purports to teach her husband as to the importance of the ship: "vos en orroiz par tens autres noveles que vos ne cuidiez" [In time you will discover more about it, things that you cannot now imagine], ${ }^{46}$ which Malory translates "ye shall hyre peradventure tydynges sonner than ye wene." 47 Moreover, her taste for display and show might be glimpsed by the advice she gives to Solomon, to refurbish the hilt of David's sword with multiple stones. As in the previous instance, the tendency to order is more characteristic of Solomon's wife in the "Sankgreal" rather than in the Queste. Thus, she declares as soon as she hears of Solomon's distress: "I shall lette make a shippe of the beste wood and moste durable that ony man may fynde." 48 As soon as the ship is finished, she commands her husband as she later commands the carpenter: "ye shall go into oure Lordis temple where ys king Davith his swerde [...] Therefore take ye that, and take off the pomelle, and thereto make ye a pomell of precious stonys." 49 While in the "Sankgreal" the wife's actions remain unexplained, in the Queste her actions are motivated by her love for Solomon and his need for advice.

In both the Queste and the "Sankgreal," Solomon's wife's social status is indicated when she discharges administrative functions; her behaviour is not unusual, because, as a woman, she is expected to oversee the household. However, when she is mentioned in connection with Solomon, her marital status ("feme," "wife") is specified, for example, when she advises Solomon to leave David's sword for his heir. In this case, she is not supervising the household routine: instead, she is involved in activities that provide for the future of her husband's lineage. Preparing the ship, Solomon's wife ensures that objects symbolizing the masculine and feminine spheres are balanced on the ship: there is David's sword refurbished by Solomon, but there is also a bed prepared by her. Moreover, there are spindles, which supply a link between the first couple, Adam and Eve, and the perfect, chaste couple, Galahad and Perceval's sister.

\footnotetext{
${ }^{46}$ Queste, 225, Quest for the Holy Grail, 138.

47 Malory, Morte, 993.

48 Malory, Morte, 992.

${ }^{49}$ Ibid.
} 


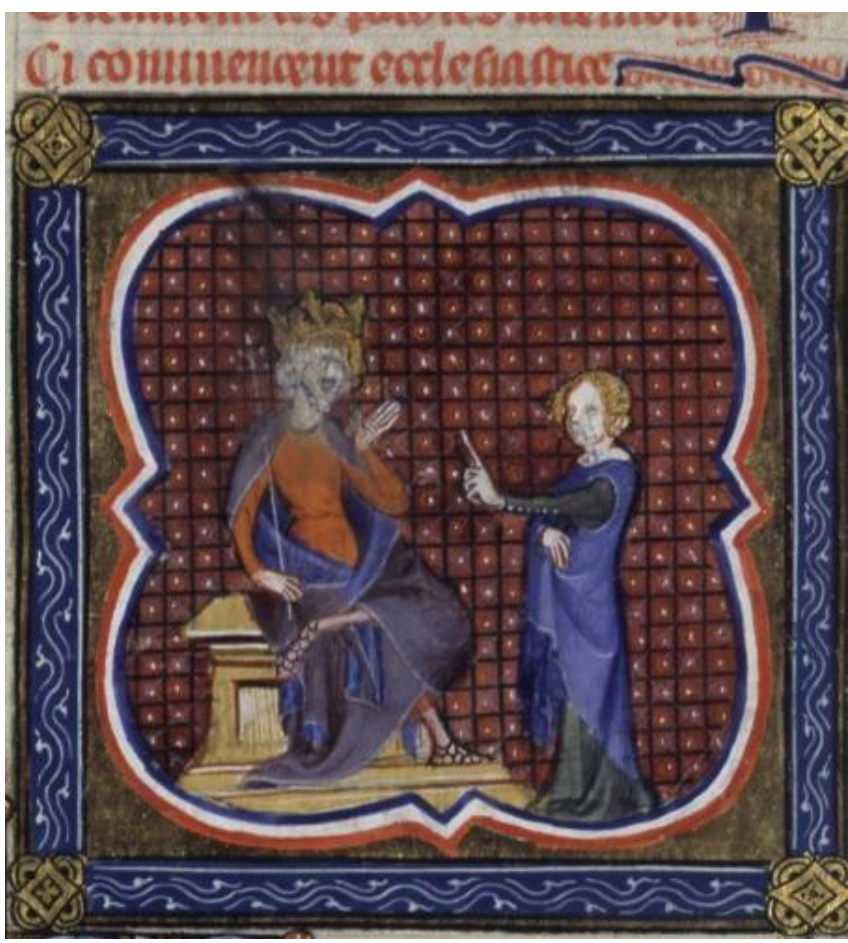

Fig. 2. Solomon and Vanity. Guiard de Moulins, Bibles Historiale, c. 1350-1375, Paris. Bibliothetque national de France, f. fr. 162, fol. 11

Throughout the Queste narrative about the building of the ship, the French author takes care to specify the characters' motivation: as has already been mentioned, Solomon is moved by the desire to communicate with his heir. However, his wife's motivation differs across texts: while in the Estoire she seems to be motivated mainly by fear, in the Queste, she is also concerned with her husband's emotional well-being, and the Queste author refers specifically to the mutual love and respect between Solomon and his wife. Although she often angers Solomon by her "grant engine," 50 her motivation in trying to find what makes Solomon uneasy is not entirely reprehensible: "ele l'amoit asez, non pas tant que maintes fames n'amassent plus lor seignors, si estoit molt viseuse" [She loved him dearly (though many wives love their

${ }^{50}$ Queste, 220. 
husbands more) and she was very shrewd]. ${ }^{51}$ Accordingly, the French author mitigates the impression left by Solomon's previous bitter observation that he could not find a good woman in all the world and at the same time praises those women who love their husbands better than Solomon's wife does. The quality mentioned last, "si estoit molt viseuse," is confusing; it may have suggested to Malory the idea that she was an "evyll wyff." However, according to the DMF, the word "viseuse" ("voiseux") can mean "habile," "avisé," "sage" [wise] as well as "rusé" [cunning].

Bearing in mind the fact that certain kinds of knowledge, including spiritual knowledge, appear as Solomon's privilege in the episode, it may appear surprising that Solomon needs his wife's advice at all. However, in the Queste, both Solomon and his wife pay mutual respect to their different types of intelligence. Asking her husband what he is concerned about, the woman declares: "il n'a ou monde chose de quoi je ne cuidasse venir a chief, au grant sens qui en vos est et a la grant subtilité qui est en moi" [there's nothing in the world that I cannot solve with your great wisdom and my great shrewdness]. ${ }^{52}$ Solomon acknowledges his wife's ingenuity, much as it baffles his understanding, and he tells her of his trouble. ${ }^{53}$ As soon as his wife learns that Solomon is preoccupied with the problem of passing a message to his distant heir, she comes up with a solution and instructs him to build a ship. Likewise, when Solomon cannot think of arms that will be good enough for the peerless knight who is to enter the ship, she suggests King David's sword. Explaining how to fashion the pommel out of precious stones, Solomon's wife again expresses her respect for Solomon's learning:

vos, qui connoissiez les vertues des pierres et la force des herbes et la maniere de toutes autres choses terrienes, si i fetes un pont de pierres precieuses si soutilment jointes qu'il n'ait aprés vos regart terrien qui poïst conoistre l'une de l'autre.

[you, who know the properties of precious stones and herbs and the way of all terrestrial things, should make a

51 Queste, 220, Quest for the Holy Grail, 136.

52 Queste, 222, Quest for the Holy Grail, 136.

${ }^{53}$ Queste, 222. 
handle of precious stones so finely joined together that no one who looks at it in the future will be able to discern one from another. $]^{54}$

Janina Traxler remarks that instructions about the pommel are the only piece of advice Solomon does not follow: he fashions the pommel of a single stone instead of joining multiple stones together. ${ }^{55}$ Meanwhile, the pommel is the only part in the design of the ship and its furnishings for which, as Solomon's wife acknowledges, the king possesses the relevant knowledge. Accordingly, in the Queste, the husband and wife co-operate to pass on to their remote descendant a matchless sword, his rightful heirloom.

The sword destined for Galahad has double symbolism. First, it establishes a connection between the knight to come and his male ancestors, Solomon and David. Second, it confirms Galahad's authority as a knight and leader, as, depending on the context, a sword can be used as a symbol of both military and judicial authority. In fact, one of the manuscripts of Guiard de Moulins' historiated Bible has a miniature where Solomon appears with Justice at the beginning of the book of Wisdom (BNF, f. fr. 164, fol. 219r): "ci commence sapience salmon" [thus begins the Wisdom of Solomon]. One of Solomon's famous qualities was, of course, his judicial wisdom, finding application in several episodes from the Bible, such as the judging of two women over a baby. In this illumination, however, Solomon is paired with abstract Justice, who appears as a royal figure, wearing a crown and handing Solomon the sword of Justice. As on the previous examples, the woman occupies the right-hand side of the miniature. She is kneeling on her left knee and is holding out a sword, hilt upwards, to Solomon. The King, again seated on a pedestal, is about to take the sword with his left hand, while the gesture of his right hand, the index finger extended, suggests that he is making a point, possibly marking the significance of the moment to the readers - and viewers - of the manuscript.

${ }^{54}$ Queste, 223, Quest for the Holy Grail, 137.

55 Janina Traxler, "Dying to Get to Sarras: Perceval's Sister and the Grail Quest," in The Grail: A Casebook, ed. Dhira Mahoney (London: Garland Publishing), 261-78 (267). 


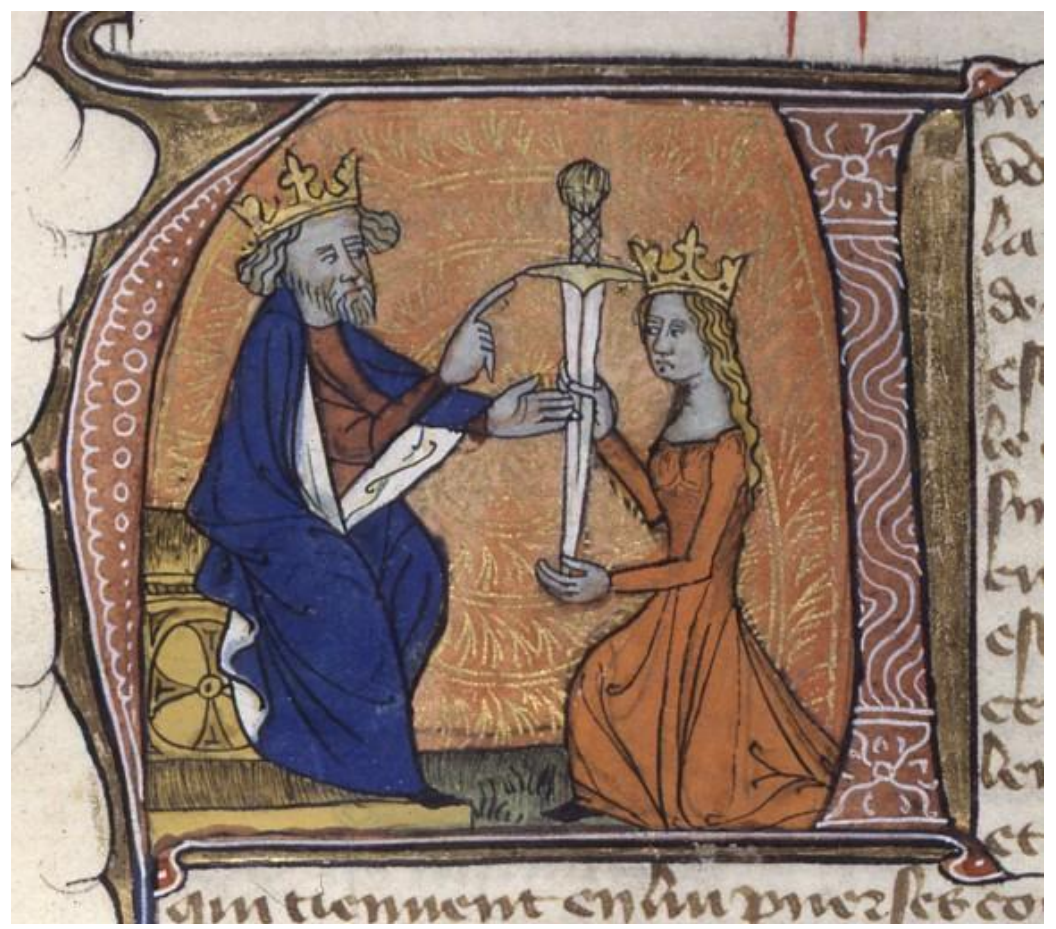

Fig. 3. Solomon and Justice. Guiard de Moulins, Bibles Historiale, c. 1375-1400, Paris. Bibliothetque national de France, f. fr. 164, fol. 219r

In this miniature, Justice is presented as an independent queen, who, nonetheless, is somewhat below Solomon in status, as signalled by her kneeling position and the less ornate crown on her head. Again, we see that Justice, portrayed as a royal lady, shows deference to Solomon. The sword, which occupies the centre of the illumination, provides the focus of attention for the characters and the manuscript viewers. Once more, we are reminded of the prominence of David's sword in the Queste, where the symbolic weapon, Galahad's destined heirloom, is the subject of care for both King Solomon and his wife.

Going back to the refurbishing of David's word in the Queste, the relation between Solomon's wisdom and his wife's cunning in the Queste is interesting when we compare Solomon's association with Wisdom, represented as a lady on a miniature at the beginning of the Ecclesiastes (BNF, f. fr. 160, fol. 255v). The miniature marks the 
beginning of the Ecclesiastes, identified by a caption in red ink: "ci commence ecclesiastez." The illumination shows Solomon and Sapientia (Wisdom) praying in front of an altar, seen through what appears to be the church entry. The altar is covered with white cloth over which is placed a golden chalice, enveloped partially in a white napkin. Both Solomon and Wisdom wear crowns: Solomon is standing behind the kneeling Sapientia, whose hands are folded in prayer. Solomon's head is lowered, and his eyes are on the chalice, to which he is also gesturing with his left hand; his right hand is lowered towards Wisdom, as if stressing her role as his superior and intercessor.

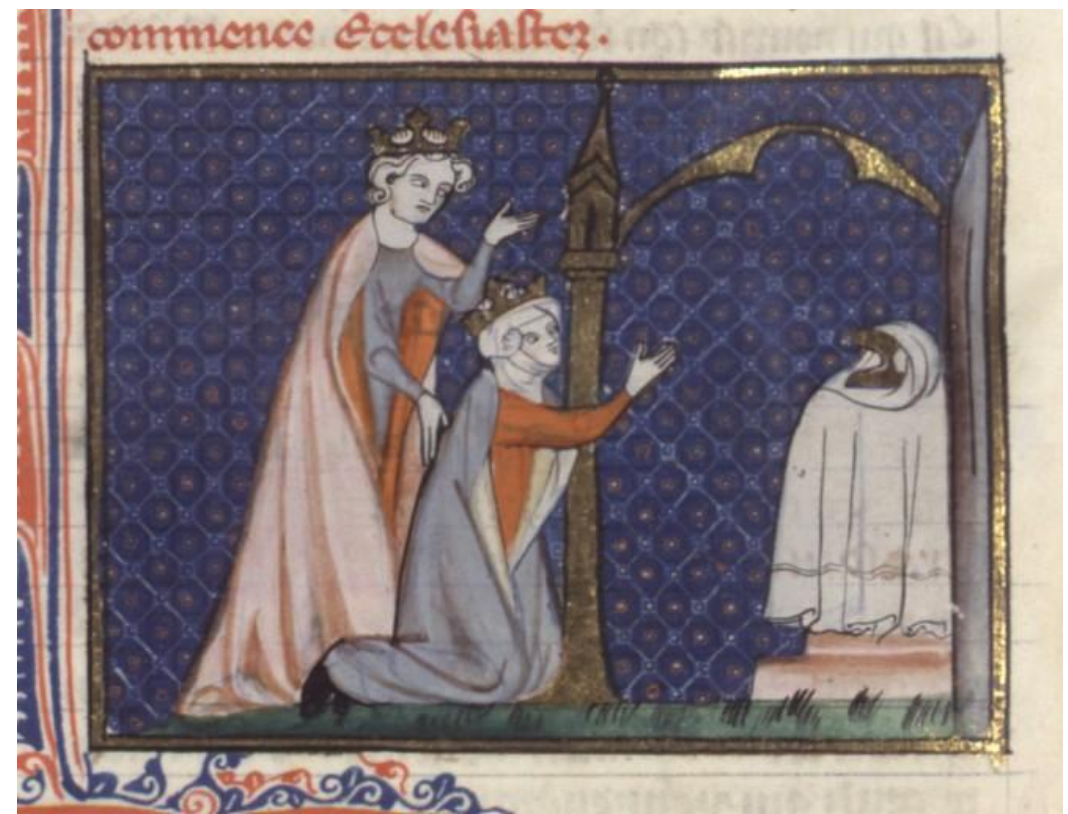

Fig. 4. Solomon and Wisdom. Guiard de Moulins, Bibles Historiale, c. 13001325, Paris. Bibliothetque national de France, f. fr. 160, fol. 255v

Here, the humility of the kneeling Wisdom underscores her spiritual superiority over Solomon: Wisdom is closer to the altar than Solomon, the latter not daring even approach the temple gate on the threshold of which Wisdom is kneeling. Solomon, in turn, can hope to enter the temple only through the intercessory prayer of Wisdom, who represents a lesson in humility and, simultaneously, an exaltation of this 
quality. Tellingly, in the Queste, Solomon's wife does manifest a degree of humility, when she highlights that neither she nor Solomon are worthy to attach a belt to the sword of David: 'il n'afiert mie a nos que nos les i metons; ainz les i metra une pucele, mes je ne sai quant ce sera, ne a quele hore' [It's not up to us to attach the proper belt to this sword. A virgin will do that, though I don't know when]. ${ }^{56}$ Thus, albeit Solomon's wife in the romance does not correspond exactly to the figure of Wisdom, being cunning ("viseuse" ${ }^{57}$ ) rather than wise, she does exhibit some attributes of Wisdom, notably humility and practical intelligence.

I have already noted that scholars often view relations between spouses in the Middle Ages as being in some ways unequal or at least as spouses having different areas of responsibility within the marriage. In the Queste, the Estoire and the "Sankgreal," revelations about the coming of Galahad are given only to Solomon. A voice from heaven speaks about the last knight of Solomon's lineage, thus obscuring the relation of Solomon's wife to their future descendant. Even the heirloom that Galahad receives, David's sword, comes from Solomon's line. Nonetheless, without Solomon's wife, this heirloom would have never reached Galahad. Baumgartner comments on the paradox: "Transmettre l'héritage, ce privilège ordinairement réservé à l'homme, ne peut en effet être assuré lorsqu'il s'agit de la vie elle-même, que par la femme" [Transmitting the heritage, a privilege usually reserved to a man, cannot be accomplished, when it comes to life itself, but by a woman]. ${ }^{58}$ Bearing in mind that women are often absent from genealogies compiled for the nobility and the gentry, unless they serve as links to other illustrious families, it is not surprising that the relation between Solomon's wife and Galahad is not voiced in the Queste and the "Sankgreal."

\section{Images of Eve, Solomon's Wife and Perceval's Sister in the Lancelot-Graal manuscripts}

The sample of illuminated manuscripts which I examined for the present work consists of 15 manuscripts of the Queste, which do not

${ }^{56}$ Queste, 223, Quest for the Holy Grail, 138.

${ }^{57}$ Queste, 221.

58 Baumgartner, Arbre, 140. 
contain the Estoire, with 6 additional manuscripts containing the Estoire, but not the Queste. The total number of examined illuminations is 2852.59

Furthermore, among the 15 manuscripts of the Queste, we can single out certain women who exercise spiritual, moral or intellectual authority over the male characters: the nuns at the abbey where Galahad is knighted at the beginning of the romance; the female recluses with whom the knights converse during the quest; and Perceval's sister, who both teaches and guides the elect knights. Arguably, Solomon's wife can be included among these influential women due to her role in constructing the ship. I have, however, excluded Eve from this group, not because as the mother of sin she is justly marginalised - so is Solomon's wife - but because her representation in both the text and the miniatures relies on the strong tradition of apocrypha and Biblical illumination, ${ }^{60}$ unparalleled for any of the above women, including Solomon's wife.

Of the above female characters, recluses make up the bulk of the group, appearing on 13 images in 10 manuscripts. ${ }^{61}$ Perceval's sister (in the Ship of Solomon episode only) and the nuns at the abbey where Galahad is knighted are represented in 7 manuscripts, but in one manuscript, BnF, f. fr. 342, Perceval's sister appears on two miniatures, on fol. $124 \mathrm{v}$ and fol. $132 .{ }^{62}$ In turn, King Solomon's wife is represented

${ }^{59}$ All the manuscripts are fully or partially digitised, and the illuminations available on the websites of their respective libraries. The illuminated manuscripts examined are BnF, f. fr. 110; BnF, f. fr. 111; BnF, f. fr. 112 (3); BnF, f. fr. 116; BnF, f. fr. 120; BnF, f. fr. 122; BnF, f. fr. 123; BnF, f. fr. 339; BnF, f. fr. 342; BnF, f. fr. 343; BnF, f. fr. 344; BnF, f. fr. 1424; BnF, f. fr. 12573; BL, Royal 14 E III; and Cologny, Bodmer 147.

60 Vita Adae et Evae, which sometimes appears as the Penitence of Adam or as an introduction to the Golden Legend, was a popular medieval apocryphal story (see Murdoch, Apocryphal Adam and Eve).

${ }^{61} \mathrm{BnF}$, f. fr. 111, ff. 243r (this miniature pictures a hermit in place of recluse; for a commentary on this, see Anastasija Ropa, "Female Authority during the Knights' Quest? Recluses in the Queste del Saint Graal," Bulletin du centre d'études médiévales d'Auxerre | BUCEMA 20.1 (2016) <http://cem.revues.org/14426>; DOI: 10.4000/cem.14426) and 244v; BnF, f. fr. 112 (3), fol. 18v; BnF, f. fr. 116, fol. 623v; BnF, f. fr. 122, fol. 229v; BnF, f. fr. 339, fol. 238v; BnF, f. fr. 342, ff. 81r-82v; BnF, f. fr. 343, fol. 21v and fol. 33v; BnF, f. fr. 344, fol. 487v; BnF, f. fr. 1424, fol. 3r; BnF, f. fr. 12573, fol. 201 r.

62 Perceval's sister in the Ship of Solomon episode: BL, Royal 14 E III, fol. 130v; BnF, f. fr. 111, fol. 262v; BnF, f. fr. 112 (3), fol. 167r; BnF, f. fr. 122, fol. 262r; BnF, f. fr. 342 , fol. 124v and fol. 132r; BnF, f. fr. 343, ff. 56r; BnF, f. fr. 1424, fol. 37r. Nuns at the abbey where Galahad is knighted: BnF, f. fr. 344, fol. 476r; BnF, f. fr. 343, fol. 1v; BnF, 
in only one manuscript of the Queste, BnF, f. fr. 112 (3), fol. 169r, making a seemingly insignificant appearance even among this group of authoritative women. The sample is not without its limitations, as it includes only those Queste manuscripts which are digitally available, and the number of illuminations across the manuscripts varies significantly.

From this sample, it appears that the statement made by several scholars that the Queste women are demonized, victimized or underrepresented should be qualified. ${ }^{63}$ Certainly, the number of illuminations portraying women during the Grail quest is far lower than the number of knights, and the knights are also more prominently represented in the narrative. On the other hand, most, or even all, women characters in the Queste appear at the crucial junctions in the narrative. Indeed, King Solomon's wife enters the narrative at the narrative climax, just as the elect knights are finally united and prepare to set off on the final stage of their quest. The episode is also significant in juxtaposing three women, Perceval's sister, Eve and Solomon's wife. In certain manuscripts, including $\mathrm{BnF}$, f. fr. 112 (3), the sequence Perceval's sister - Eve - Solomon's wife - Perceval's sister - is fully or partially reresented in the accompanying illuminations.

Solomon's wife and Perceval's sister remain unnamed. They are identified instead by reference to the men of their family. At the same time, they also break beyond the family control, as they make history for their men and become responsible for preserving and passing on the male heritage: in fact, female anonymity was a common feature of medieval genealogies, with only very few illustrious - or, like Eve, notorious - women mentioned by name. Being nameless, thus, can be a mark of humility in the Queste universe. Meanwhile, the near invisibility

f. fr. 123, fol. 197r; BnF, f. fr. 120, fol. 522v; BnF, f. fr. 116, fol. 607v; BnF, f. fr. 112 (3), fol. 1v; BnF, f. fr. 111, fol. 236r.

${ }^{63}$ Janina Traxler and Maureen Fries describe Perceval's sister as the only prominent woman in the narrative, who must be sacrificed if the Grail quest is to be completed. Fries contends that Perceval's sister is "a late medieval and much adapted version of the female hero conflated with the female saint" (Maureen Fries, "Gender and the Grail," Arthuriana 8:1 (1998): 67-79 (77)). Traxler describes Perceval's sister as an "Arthurian Virgin Mary" and continues to point out that "the portrayal of Perceval's sister [...] displays many of the dominant traits of thirteenth-century hagiography" (Traxler, "Dying to Get to Sarras," 261-78, 266 and 271). On the angel-demon dichotomy of female characters in the Queste, see Jeannine Horowitz, "La Diabolisation de la sexualité dans la littérature du Graal au XIIIe siècle: Le cas de La Queste del Saint Graal," in Arthurian Romance and Gender, ed. F. Wolfzettel (Amsterdam: Rodopi, 1995), 238-50. 
of Solomon's wife is tantalizing: is her image too insignificant or too disquieting for the illuminators, patrons and audiences? Meanwhile, Solomon himself appears in only four of the Queste and the Estoire manuscripts: BnF, f. fr. 749, fol. 52v (Estoire) and BnF, f. fr. 112 (3), fol. 169r (Queste) - with his wife; and BnF, f. fr. 105, fol. 68r (Estoire) and $\mathrm{BnF}$, f. fr. 9123, fol. 57r (Estoire) - without his wife. In fact, there is only one manuscript, the richly illuminated $\mathrm{BnF}$, f. fr. 112 (3) where all three women - Perceval's sister, Eve and Solomon's wife - are drawn for each part of the episode. Before examining this exuberant late medieval manuscript, however, let us turn to an earlier appearance of Solomon's wife in the Estoire in BnF, f. fr. 749.

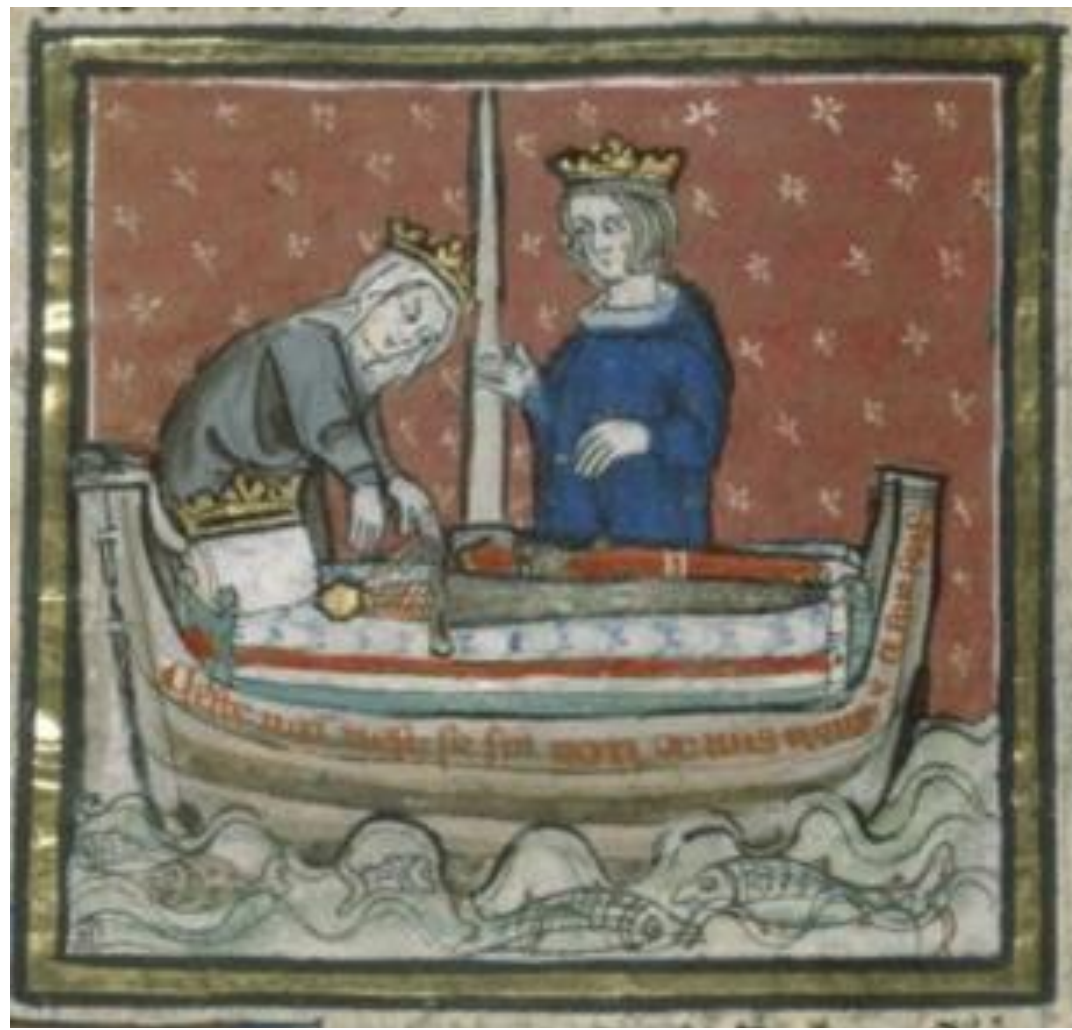

Fig. 5. Solomon and his wife on the ship. Estoire del Saint Graal, 1280-1290, Flanders, Belgium. Bibliothetque national de France, f. fr. 749, fol. 52v 
The manuscript, produced at the end of the thirteenth century in Thérouanne or Ghent, Flanders, includes the Estoire del Saint Graal and Merlin romances of the Lancelot-Graal cycle. ${ }^{64}$ The entire manuscripts contains 126 illuminations, 28 of them miniatures of the Estoire (fols. 1122). The miniature on fol. $52 \mathrm{v}$ shows King Solomon and his wife, her head modestly covered, both crowned, on board the Ship. The ship is inscribed with the words in red, identifying it as the Ship of Faith (this detail is mentioned in the text). Thus, the illuminator would have either read the relevant portion of the text or have been given detailed instructions for the miniature. If the artist had read the text or was given guidelines for the miniature, this could have influenced the representation of Solomon's wife in the illumination, too.

In the miniature, Solomon occupies the space on the right-hand side, while his wife, on the left-hand side, is leaning towards the sword, which, like on the above-mentioned miniature of Solomon with Justice, is in the centre of the miniature and the ship. The sword is placed on the bed, which is the heirloom fashioned for Galahad by Solomon's wife. In front of the wife, there is a pillow topped with the crown destined for Solomon's royal descendant. Between King Solomon and his wife is the white spindle or bedpost, which, like the red and green spindles, was carved from the Tree of Life. ${ }^{65}$ The hilt of the sword is coloured gold, contrary to the text, which specifies that the hilt was of a single multicoloured stone (this would be hard to depict on a miniature, anyway). Solomon's wife is leaning, both hands extended, towards the sword, while King Solomon is looking down at the sword, and, judging by his gestures, seems to be speaking. The subject of their attention may be the hangings suitable for the marvellous sword, and Solomon may be expressing his discontent with the hemp hangings provided by his wife. Thus, the episode represents a moment of high tension in the narrative, where the preparation of the heirlooms for Galahad is nearly complete.

In a late manuscript of the Lancelot-Graal cycle, the deposition of David's sword on Soomon's ship is depicted again, as identified by a caption in red ink. The manuscript in question is the richly illuminated

\footnotetext{
${ }^{64}$ For further discussion of the manuscript and its Merlin text, see I. Fabry-Tehranchi, Texte et images des manuscrits du Merlin et de la Suite Vulgate (XIIIe-XVe siècle) (Turnhout: Brepols, 2014).

65 On the colour symbolism of the spindles, see Looper, "Gender," 52.
} 
BnF, f. fr. 112 (3), a special version executed for Jacques d'Armagnac, which includes 258 illuminations by Evrard d'Espingues. Susan A. Blackman describes the manuscript as a "unique compilation of Arthurian romances." According to Blackman, BnF, f. fr. 112 and two other manuscripts of the Lancelot-Graal romances (BnF, f. fr. 113-116 and BnF, f. fr. 117-120) were produced in such a way that their miniature cycles "interrelate," resulting in an "exhaustive and largely non-repetitive visual synopsis of Arthurian episodes that emphasizes the completeness of the narrative." 66 Moreover, Blackman notes that, in $\mathrm{BnF}$, f. fr. 112, new illustrated subjects are added, as compared to other Lancelot-Graal manuscript owned by Jacques d'Armagnac. On the other hand, the images in themselves are not entirely original, in the sense that the illuminator, Evrard d'Espingues, built on the previous iconographic tradition of the Lancelot-Graal illuminated and other works, such as historiated Bibles.

The illumination of King Solomon and his wife in the ship is not a stand-alone miniature of the Ship of Solomon episode in BnF, f. fr. 112 (3). Almost every part of the episode benefits a separate illustration, and sometimes even two illustrations, many of which have close parallels in $\mathrm{BnF}, \mathrm{f}$. fr. 113-116. On the opening miniature of the episode, fol. 167r of BnF, f. fr. 112 (3), we see the elect knights and Perceval's sister in the ship; the miniature is similar to $\mathrm{BnF}$, f. fr. $113-116$, fol. $654 \mathrm{v}$, with Perceval's sister and two of the elect knights approaching the ship in a boat. The miniature concluding the episode in BnF, f. fr. 112 (3), fol. 170r, shows Perceval reading the letter that tells the story of the ship; Perceval stands in front of the sword of David, while Galahad and Bors marvel at the three colored spindles. A similar scene occurs in $\mathrm{BnF}, \mathrm{f}$. fr. 113-116, fol. 661r, though here the spindles are not depicted, and Galahad and Bors lean to Perceval, wondering at the letter; the sword is placed in front of the three knights. In between, the audience are shown the events of the narrative read by Perceval: thus, BnF, f. fr. 113-116, shows the initial sin and the eviction of Adam and Eve from paradise, respectively on fol. $657 \mathrm{v}$ and fol. $658 \mathrm{v}$.

66 Susan A. Blackman, "A Pictorial Synopsis of Arthurian Episodes for Jacques d'Armagnac, Duke of Nemours," in Word and Image in Arthurian Literature, ed. Keith Busby (London: Routledge, 1996), 3-57 (3). 


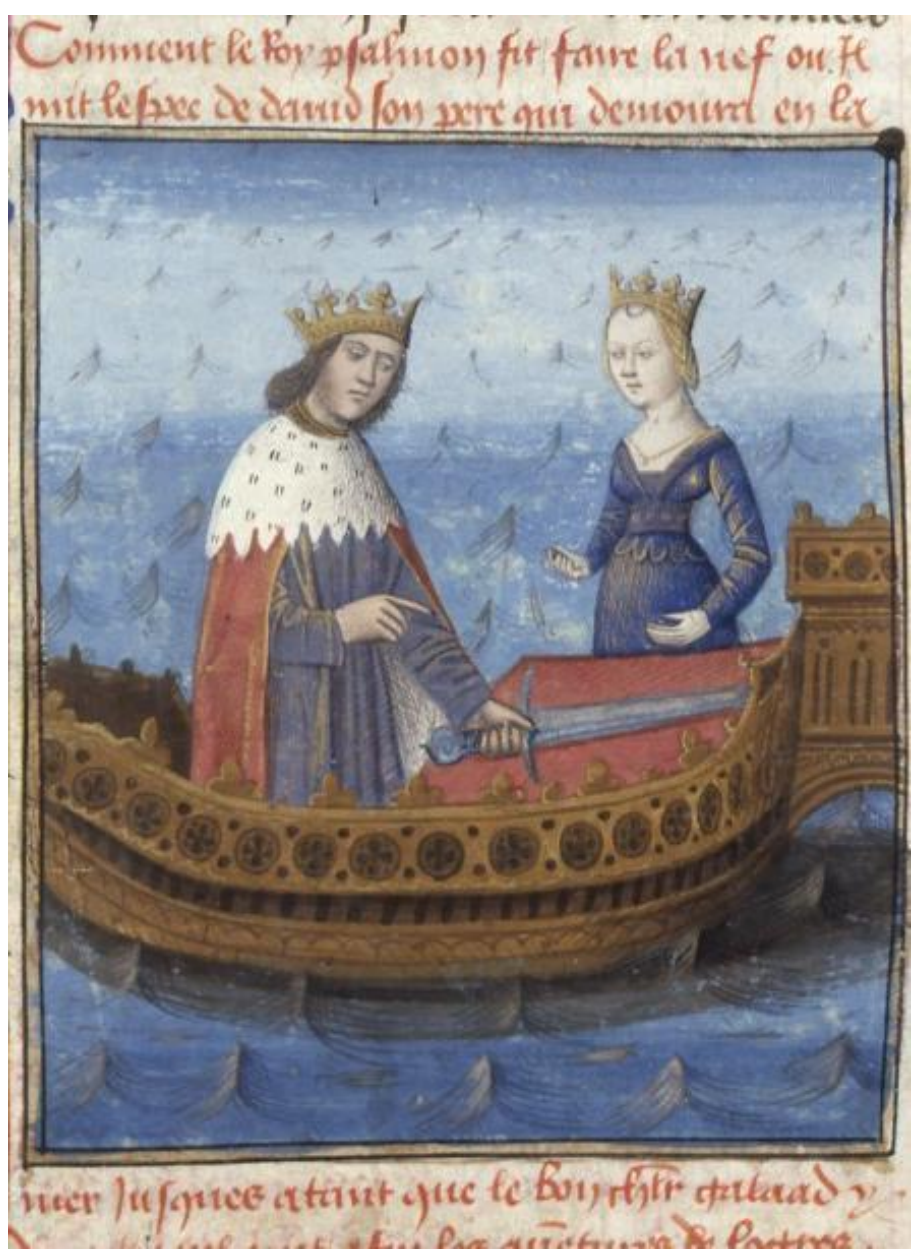

Fig. 6. Solomon and his wife on the ship. Queste del Saint Graal, c. 1470, Central France. Bibliothetque national de France, f. fr. 112 (3), fol. 169r.

As compared to the image of King Solomon and his wife on board the ship in the earlier Flemish manuscript, discussed above $(\mathrm{BnF}, \mathrm{f}$. fr. 749, fol. 52v), the positions of Solomon and his wife undergo an interesting reversal in $\mathrm{BnF}$, f. fr. 112 (3). In the latter manuscript, Solomon is holding the sword by its handle in his left hand, as if asserting his possession of the sword even as he deposits it on a red- 
clothed table for his future heir. Solomon's head is inclined towards the sword, and he is pointing to it with his right hand, stressing the significance of the object. Solomon appears to dominate the miniature: he is larger, placed in the foreground, and distinguished by visually striking, multi-coloured clothes - a royal crown, blue tunic, red mantle, and wide ermine collar.

Like Solomon, his wife is wearing a crown; her hair is hidden in a net, and jewellery glistens on her forehead, but her simple blue dress tends to blur with the surrounding sea. Her figure is reticent, drawn behind the table on which the sword is being placed. Her arms and hands are slightly raised, as if she were spinning - or holding an invisible child, and she is looking down. Compared to the assertive Solomon, she is a respectful, even humble character, much like Perceval's sister, who is hidden behind the male questors on the previous folio in the manuscript (fol. 167r). At the same time, the gesture of Solomon's wife indicates that she, too, has an heirloom to pass to Galahad: the spindles which mark the line of descent from Adam and Eve through David and Solomon to the virgin knight. The very reticence of Solomon's wife is a mark of her significance in the story, a woman who is uncelebrated, yet indispensable. Without women, a dynasty cannot continue, and, without her practical wisdom, Solomon would not have known how to communicate the early history of Galahad's line to the Grail knight.

\section{Conclusion. The Complex Image of Solomon's Wife}

Solomon's wife appears in three texts that deal with the Grail quest: two romances from the Lancelot-Graal cycle (the Estoire del Saint Graal and the Queste del Saint Graal) and Thomas Malory's "Tale of the Sankgreal," which closely follows the Queste. The texts tell the same story of the building of Solomon's ship, but characterize Solomon's wife in slightly different ways; she appears on illuminations in two manuscripts, one for the Estoire and one for the Queste. In the Queste, which describes Solomon's wife with psychological depth, she loves Solomon, but her love is not total. She is ambitious and wants to rule, not just to obey her husband. In fact, she is gifted with practical intelligence, which, although no match for Solomon's wisdom, enables her to find an ingenious solution to Solomon's problem of communicating with his future descendant, Galahad. Her practical 
ingenuity is celebrated, yet her ambitions are disparaged. In the two later texts, she is characterized simplistically as a bad wife, who is motivated by fear and greed for power rather than by charity.

The ambivalent character of Solomon's wife is partially hinted at in the Queste and the Estoire miniatures, where she and Solomon deposit Galahad's heirloom on board the ship. The illuminators use such means as gesture, poise, positioning and colour to suggest the respective standing of Solomon and the woman, as well as their characters. The portrayal of Solomon's wife in both textual and visual sources, and, in particular, her moral ambiguity is paralleled in miniatures from historiated Bibles that show Solomon with female figures, which either evoke characters from the Bible (the Queen of Sheba) or function as allegories (Vanity, Wisdom, Justice). In fact, Solomon's wife in the Grail quest narratives demonstrates traces of all these female figures as represented in illuminations: she can be deferring and humble, as the Queen of Sheba, but she is also as assertive as Vanity. She invokes authority when she becomes involved in passing David's sword to Galahad, and her practical wisdom ("engin") is acknowledged by Solomon himself.

The differences between the image of Solomon's wife in these three texts can be traced to the context in which the texts were written and read, especially the conflicting discourses on gender, family and heredity in France and England between the thirteenth and the fifteenth centuries. The disturbing, chameleonic personality of Solomon's wife in the narrative and the multiplicity of female models associated with King Solomon in contemporary iconography probably discouraged most of the manuscript patrons and illuminators from depicting this ambiguous woman in the accompanying miniatures.

\section{Bibliography}

Primary sources

L'Estoire del Saint Graal, ed. by Jean-Paul Ponceau. Paris: Champion, 1997.

La Queste del Saint Graal, Roman du XIII siècle, ed. Albert Pauphilet, 3 ${ }^{\text {rd }}$ edn. Paris: Champion, 1923.

Malory, Thomas. The Works of Sir Thomas Malory, ed. Eugene Vinaver, $3^{\text {rd }}$ rev. edn. P. J. C. Field, vol. 2. Oxford: Clarendon, 1990. 
The History of the Holy Grail, trans. Carol Chase. Cambridge: D. S. Brewer, 2010.

The Quest for the Holy Grail, trans. Jane Burns. The Old French Arthurian $V$ ulgate and Post-Vulgate in Translation. Cambridge: D. S. Brewer, 2010.

\section{Secondary sources}

Archer, Rowena. "'How ladies... who live on their manors ought to manage their households and estates': Women as Landholders and Administrators in the Later Middle Ages." In Woman is a Worthy Wight: Women in English Society c. 1200-1500, ed. P. J. P. Goldberg, 149-181. Stroud: Alan Sutton, 1992.

Baumgartner, Emmanuèle. L'Arbre et le Pain, Essai sur la Queste del Saint Graal. Paris: S.E.D.E.S., 1981.

Blackman, Susan A. "A Pictorial Synopsis of Arthurian Episodes for Jacques d'Armagnac, Duke of Nemours." In Word and Image in Arthurian Literature, ed. Keith Busby, 3-57. London: Routledge, 1996.

Bogdanow, Fanni. "Little Known Codex, Bancroft ms. 73, and its Place in the Manuscript Tradition of the Vulgate Queste del Saint Graal." Arthuriana 6:1 (1996): 1-21.

Davidson, Roberta. "The 'Freynshe booke' and the English Translator: Malory's Originality Revisited.” Translation and Literature 17:2 (2008): 133-49.

Denton, Jon. "Genealogy and Gentility: Social Status in Provincial England." In Broken Lines: Genealogical Literature in Medieval Britain and France, ed. Raluca Radulescu and Edward Kennedy, 143-158. Turnhout: Brepols, 2008.

Duby, Georges, Love and Marriage in the Middle Ages, trans. Jane Dunnett. Chicago: University of Chicago Press, 1988.

Fabry-Tehranchi, I. Texte et images des manuscrits du Merlin et de la Suite Vulgate (XIIle-XVe siècle). Turnhout: Brepols, 2014.

Fichte, Joerg. From Camelot to Obamalot: Essays on Medieval and Modern Arthurian Literature. Trier: Wissenschftlicher, 2010.

Field, P. J. C. "Malory and the Grail." In The Grail, the Quest and the World of Arthur, ed. Norris Lacy, 141-155. Cambridge: D. S. Brewer, 2008.

Fries, Maureen. "Gender and the Grail." Arthuriana 8:1 (1998): 67-79. 
Griffin, Miranda. The Object and the Cause in the Vulgate Cycle. London: Legenda, 2005.

Horowitz, Jeannine. "La Diabolisation de la sexualité dans la littérature du Graal au XIIIe siècle: Le cas de La Queste del Saint Graal." In Arthurian Romance and Gender, ed. F. Wolfzettel, 238-50. Amsterdam: Rodopi, 1995.

Ihle, S. N. Malory's Grail Quest: Invention and Adaptation in Medieval Prose Romance. London: University of Wisconsin Press, 1983.

Locke, Frederick, The Quest for the Holy Grail: A Literary Study of a Thirteenth-Century French Romance. Stanford: Stanford University Press, 1960.

Looper, Jennifer. "Gender, Genealogy, and the 'Story of the Three Spindles' in the Queste del Saint Graal." Arthuriana 8:1 (1998): 49-66.

Mahoney, Dhira. "The Truest and Holiest Tale: Malory's

Transformation of La Queste del Saint Graal." In Studies in Malory, ed. James Spisak, 109-28. Kalamazoo: Medieval Institute Publications, 1985.

Mann, Jill. "Malory and the Grail Legend." In A Companion to Malory, ed. Elizabeth Archibald and A. S. G. Edwards, 203-220. Cambridge: D. S. Brewer, 1996.

Matarasso, Pauline. The Redemption of Chivaly: A Study of the Queste del Saint Graal. Genève: Droz, 1979.

McCarthy, Terence. "Malory and His Sources." In A Companion to Malory, ed. Elizabeth Archibald and A. S. G. Edwards, 75-95. Cambridge: D. S. Brewer, 1996.

Moorman, Charles. "Malory's Treatment of the Sankgreal." PMLA 71 (1956): 496-509.

Moorman, Charles. “The Tale of the Sankgreall': Human Frailty.” In Malory's Originality: A Critical Study of Le Morte Darthur, ed. R. M. Lumiansky, 184-204. Baltimore: Johns Hopkins Press, 1964.

Murdoch, Brian. The Apocryphal Adam and Eve in Medieval Europe: Vernacular Translations and Adaptations of Vita Adae et Evae. Oxford: Oxford University Press: 2009.

Norris, Ralph. Malory's Library: The Sources of the Morte Darthur. Cambridge: D. S. Brewer, 2008.

Pauphilet, Albert. Études sur La Queste del Saint Graal' attribué à Gautier Map. Paris: Champion, 1921. 
Pickford, C. E. “Antoine Vérard: Éditeur du Lancelot et du Tristan.” In Mélanges de langue et littérature françaises du Moyen Âge et de la Renaissance offerts à Charles Foulon, vol. 1, 280-84. Rennes: Institut de français, Université de Haute-Bretagne, 1980.

Radulescu, Raluca. "Review of Burns, E. Jane. The Quest for the Holy Grail. The Old French Vulgate and Post-Vulogate in Translation." The Medieval Review (2011) http://hdl.handle.net/2022/13321 (accessed 2 December 2016).

Regalado, Nancy. "The Medieval Construction of the Modern Reader: Solomon's Ship and the Birth of Jean de Meun." Yale French Studies 95 (1999): 81-10.

Ropa, Anastasija. 'Female Authority during the Knights' Quest? Recluses in the Queste del Saint Graal," Bulletin du centre d'études médiévales d'Auxerre | BUCEMA 20.1 (2016) <http://cem.revues.org/14426>; DOI: 10.4000/cem.14426.

Stones, Alison. "Seeing the Grail, Prolegomena to a Study of Grail Imagery in Arthurian Manuscripts." In The Grail: A Casebook, ed. Dhira Mahoney, 301-66. London: Garland Publishing, 2000. Janina Traxler. "Dying to Get to Sarras: Perceval's Sister and the Grail Quest." In The Grail: A Casebook, ed. Dhira Mahoney, 261-78. London: Garland Publishing, 2000.

Tucker, P. E. "The Place of the Quest of the Holy Grail in the Morte Darthur." MLR 48 (1953): 391-97.

Winn, Mary. "Vérard's Editions of Tristan." Arthuriana 19:1 (2009): 4773.

Zink, Michel. L'Humiliation, le Moyen Age et nous. Paris: Albin Michel, 2017.

\section{Acknowledgements}

The present article builds on my doctoral research completed at Bangor University, UK, between 2009 and 2014. I would like to thank my supervisors, Dr. Raluca Radulescu and Prof. Tony Brown, for encouraging me to study minor and marginal characters of Arthurian romance, and for providing their feedback on my earlier research into the Ship of Solomon episode. Likewise, I am very grateful to the thesis examiners, Dr. Jane Gilbert and Prof. Helen Wilcox.

I am equally grateful to Dr. Monica Ann Walker Vadillo for accepting my proposal at the International Medieval Congress in Leeds, 
2015, offering me an opportunity to engage with the artistic aspect of my medieval sources closer than I was able to do in the course of my doctoral research.

Finally, I would like to thank Prof. Barbara Newman for her feedback at the masterclass "Gender, Religion, and the Power of Resistance in the High and Late Middle Ages" at the Brussels Free University, 16 June 2016, where I presented my research on the portrayal of women in the Queste del Saint Graal, and, in particular, for confirming my intuition that Solomon's wife exhibits some characteristics of Wisdom and Sovereignty in this romance. 